\title{
Laser recanalisation of coronary arteries by metal- capped optical fibres: early clinical experience in patients with stable angina pectoris
}

\author{
FILIPPO CREA, GRAHAM DAVIES, WILLIAM J MCKENNA, \\ MEHDI PASHAZADEH, * BRUCE KEOGH, PETER KIDNER, * \\ KENNETH M TAYLOR, ATTILIO MASERI
}

From the Division of Cardiovascular Diseases and Cardiothoracic Surgical Unit, Royal Postgraduate Medical School, Hammersmith Hospital, London and `Division of Cardiovascular Diseases, St Mary's Hospital, London

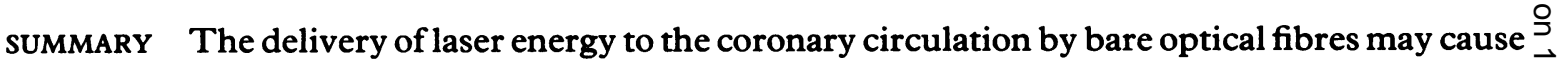
perforation of the vessel. Experimental studies have shown that this complication can be avoided if 7 the optical fibre is fitted with a metal cap to prevent the potentially dangerous forward projection of $\frac{\mathbb{D}}{2}$ the laser beam. This study was performed to assess the feasibility and short term effects of percutaneous coronary laser recanalisation with these modified fibres. Recanalisation of a severe ${ }^{\gtrless}$ stenosis of the left anterior descending artery was attempted in six patients who were referred for $\vec{\emptyset}$ coronary artery bypass grafting. Although the percutaneous technique was used, the laser ${ }^{\circ}$ procedure was performed during coronary bypass surgery before the start of cardiopulmonary bypass to minimise the effects of potential complications. A $1.5 \mathrm{~mm}$ diameter metal-capped fibre coupled to an argon laser was advanced percutaneously over a guide wire positioned across the stenosis. In the first patient the delivery of $152 \mathrm{~J}$ resulted in the gradual passage of the fibre through a $3 \mathrm{~cm}$ long stenosis. Repeat angiography showed a reduction in the severity of the stenosis. In the second patient the delivery of $112 \mathrm{~J}$ failed to allow fibre advancement; a further $80 \mathrm{~J}$ pulse caused perforation which was repaired. In the remaining four patients the delivery of laser energy in the attempt to traverse the stenosis was limited to less than $90 \mathrm{~J}$. In two of the four patients the severity of stenosis was reduced. No further complications were seen.

Percutaneous coronary laser recanalisation with metal-capped optical fibres is feasible but improvements of currently available technology are needed to increase the primary success rate.

Experimental and clinical studies have shown that laser energy transported by optical fibres can recanalise atherosclerotic arteries. ${ }^{1-3}$ Dissection, distal embolisation, thrombosis, and aneurysm formation are uncommon complications. ${ }^{4-6}$ Laser recanalisation may be successful in arteries in which occlusion prevents the passage of a balloon catheter. ${ }^{7}$ Furthermore, laser technology can remove the atherosclerotic plaque rather than remodel it ${ }^{8-10}$; and this could result in a lower restenosis rate than that seen after balloon angioplasty. Despite these theoretical advantages, use of this new technique in the coronary

Requests for reprints to Dr Filippo Crea, Cardiovascular Unit, Royal Postgraduate Medical School, Hammersmith Hospital, Ducane Road, London W12 0HS.

Accepted for publication 29 September 1987 circulation has been hampered by the problem of $\delta$ arterial perforation-mainly caused by the difficulty of controlling the direction of the laser beam in 의 tortuous arteries within the beating heart. ${ }^{11}{ }^{12}$

Several modifications of the technique described in early experiments have been proposed to reduce $\bar{N}$ the risk of perforation. These include use of pulsed $\mathrm{Or}$ lasers to achieve tissue ablation without thermal 0 damage, ${ }^{13-15}$ improvement of the guiding system by $\tilde{\omega}$ means of angioscopy or laser-induced fluorescence $\sigma$ detection, ${ }^{16-18}$ development of less traumatic delivery 0 systems to avoid mechanical perforation, ${ }^{1920}$ and $\overparen{D}$ selective enhancement of laser energy absorption by $\stackrel{\mathscr{P}}{?}$ the atherosclerotic plaque..$^{21-23}$

Another approach is to prevent the potentially dangerous forward projection of the laser beam by crimping a metal cap on to the tip of the optical fibre. Experimental and clinical studies have shown that 
the heat generated by the interaction of laser energy with the metal cap is sufficient to recanalise occluded peripheral arteries by vaporisation of the atherosclerotic plaque. ${ }^{24-27}$ We have previously demonstrated in live dogs that the intracoronary delivery of laser energy through metal-capped fibres allows a precisely targeted intimal vaporisation without perforation..$^{28}$ Based on these results we have assessed the feasibility of performing percutaneous coronary laser recanalisation in patients with stable angina pectoris by means of metal-capped optical fibres. The fibres we used in the coronary circulation are different from those used in peripheral arteries. ${ }^{2425} 27$ They have a channel through the metal cap which allows the passage of a conventional angioplasty guide wire; this can be positioned across the stenosis before the optical fibre is advanced. The guide wire facilitates both positioning and centralisation of the metal cap. To minimise the effects of potential complications the procedure was performed at the time of coronary bypass surgery after pericardiotomy but before the institution of cardiopulmonary bypass.

\section{Patients and methods}

\section{PATIENTS}

Six patients (all men, aged 54-71, mean 59 years) with multivessel coronary disease and stable angina pectoris refractory to medical treatment who were referred for routine coronary artery bypass grafting were studied. All had a significant stenosis (from $70^{\circ}{ }_{0}$ to $80^{\circ}{ }_{0}$, reduction in internal lumen diameter) of the left anterior descending artery. Laser recanalisation of only this artery was attempted. Table 1 shows the clinical and angiographic details. The approval of the ethics committee and the written informed consent of patients were obtained.

\section{PROTOCOL}

After sternotomy, pericardiotomy, cannulation of the ascending aorta, and administration of heparin $(300 \mathrm{IU} / \mathrm{kg})$, a $9 \mathrm{~F}$ arterial sheath was placed in the right femoral artery. The tip of a $9 \mathrm{~F}$ guiding catheter was positioned, via the sheath, into the left coronary ostium and an angiogram was obtained. In the operating theatre angiography was recorded from fluoroscopy on to videotape; although the quality of the images was not as good as that provided by cineangiography, it was satisfactory for performing the procedure safely. A 0.012 inch diameter, $300 \mathrm{~cm}$ long Kaltenbach steerable guide wire was advanced across the left anterior descending artery using conventional angioplasty techniques and the stenosis was crossed. A $300 \mu \mathrm{m}$ core optical fibre fitted with a $1.5 \mathrm{~mm}$ metal cap (Trimedyne Inc, Santa Ana, California) was coupled to an argon laser generator. Coupling and transmission efficiency, assessed before the procedure with a $300 \mu \mathrm{m}$ bare optical fibre, was found to be $90^{\circ}{ }_{0}$. The metal-capped end of the fibre (fig 1) was then advanced over the guide wire (accommodated in a tunnel through the metal cap) to the site of the stenosis in the left anterior descending artery. When no further advancement could be achieved, a $6 \mathrm{~W}$ laser pulse was delivered for 4-6 s (energy 24-36 J). During laser delivery gèntle pressure was applied to advance the fibre through the stenosis. If the stenosis was not crossed further laser pulses of $8 \mathrm{~W}$ for exposure times of up to $8 \mathrm{~s}$ were delivered. After the stenosis had been crossed, the fibre was advanced during the cooling period for 1-2

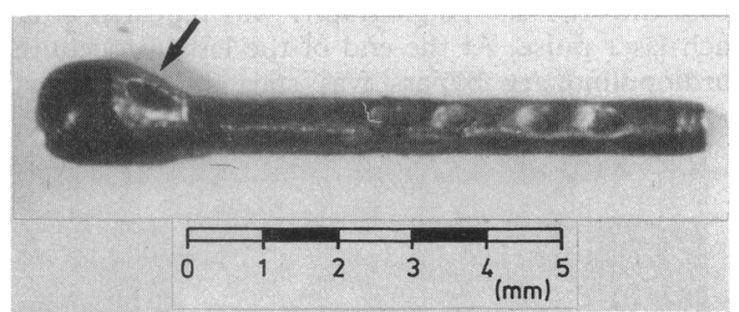

Fig 1 Photomicrograph of the $1.5 \mathrm{~mm}$ metal-capped optical fibre. The arrow shows the entry point of the channel for the passage of the guide wire.

Table 1 Characteristics of six patients studied

\begin{tabular}{|c|c|c|c|c|c|c|}
\hline \multirow[b]{2}{*}{ Patient No } & \multirow[b]{2}{*}{ Age/sex } & \multirow{2}{*}{ Angina duration (y) } & \multirow[b]{2}{*}{ Basal ECG } & \multicolumn{3}{|c|}{ Baseline angiography (" "stenosis) } \\
\hline & & & & $L A D\left({ }^{\prime}{ }_{0}\right)^{\star}$ & $C x\left({ }_{0}^{0}\right)$ & $R C A\left({ }^{\circ} \circ\right)$ \\
\hline $\begin{array}{l}1 \\
2 \\
3 \\
4 \\
5 \\
6\end{array}$ & $\begin{array}{l}61 / M \\
71 / M \\
60 / M \\
54 / M \\
56 / M \\
56 / M\end{array}$ & $\begin{array}{r}2 \\
10 \\
2 \\
11 \\
3 \\
10\end{array}$ & $\begin{array}{l}\text { Qw V1-V3t } \\
\text { Normal } \\
\text { Qw II-III aVFt } \\
\text { Normal } \\
\text { Normal } \\
\text { Qw II-III aVF't }\end{array}$ & $\begin{array}{l}80(3 \mathrm{~cm}) \\
80(3 \mathrm{~cm}) \\
80(1 \mathrm{~cm}) \\
80(1 \mathrm{~cm}) \\
70(1 \mathrm{~cm}) \\
70(1 \mathrm{~cm})\end{array}$ & $\begin{array}{l}90 \\
\text { Normal } \\
\text { Normal } \\
90 \\
70 \\
100\end{array}$ & $\begin{array}{l}\text { Normal } \\
90 \\
90 \\
70 \\
90 \\
80\end{array}$ \\
\hline
\end{tabular}

Cx, circumflex artery; ECG, electrocardiogram; LAD, left anterior descending artery; $Q w, Q$ wave; RCA, right coronary artery. ${ }^{\star}$ Length of the stenosis is shown in parentheses.

$\uparrow$ Myocardial infarction occurred 2-10 years before the study. 


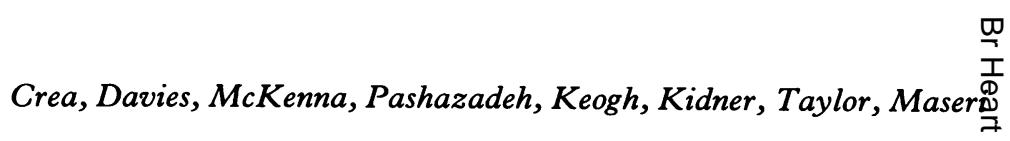

Table 2 Values of laser energy delivered in six patients, effects on the severity of the left anterior artery stenosis, anc. complications

\begin{tabular}{|c|c|c|c|c|c|c|c|}
\hline \multirow{2}{*}{$\begin{array}{l}\text { Patient } \\
\text { No }\end{array}$} & \multirow{2}{*}{$\begin{array}{l}\text { Laser } \\
\text { pulses (No) }\end{array}$} & \multirow{2}{*}{$\begin{array}{l}\text { Power } \\
\text { (W) }\end{array}$} & \multirow{2}{*}{$\begin{array}{l}\text { Duration } \\
\text { (s) }\end{array}$} & \multirow{2}{*}{$\begin{array}{l}\text { Energy } \\
(J)\end{array}$} & \multirow{2}{*}{$\begin{array}{l}\text { Fibre } \\
\text { progression }\end{array}$} & \multicolumn{2}{|c|}{ Repeat angiography } \\
\hline & & & & & & $L A D$ stenosis & Acute complications \\
\hline 1 & $\begin{array}{r}1 \\
2 \\
3 \\
4 \\
\star 5\end{array}$ & $\begin{array}{r}6 \\
8 \\
8 \\
8 \\
10\end{array}$ & $\begin{array}{r}4 \\
6 \\
6 \\
4 \\
10\end{array}$ & $\begin{array}{r}24 \\
48 \\
48 \\
32 \\
100\end{array}$ & $\begin{array}{l}\text { No } \\
\text { Yes } \\
\text { Yes } \\
\text { Yes } \\
\text { Yes }\end{array}$ & Improved & None \\
\hline 2 & $\begin{array}{l}1 \\
2 \\
3 \\
4\end{array}$ & $\begin{array}{l}6 \\
8 \\
8 \\
8\end{array}$ & $\begin{array}{r}4 \\
6 \\
5 \\
10\end{array}$ & $\begin{array}{l}24 \\
48 \\
40 \\
80\end{array}$ & $\begin{array}{l}\text { No } \\
\text { No } \\
\text { No } \\
\text { No }\end{array}$ & Unchanged & LAD Perforation \\
\hline 3 & $\begin{array}{r}1 \\
2 \\
3 \\
\star 4\end{array}$ & $\begin{array}{l}6 \\
8 \\
8 \\
8\end{array}$ & $\begin{array}{l}6 \\
3 \\
3 \\
6\end{array}$ & $\begin{array}{l}36 \\
24 \\
24 \\
48\end{array}$ & $\begin{array}{l}\text { No } \\
\text { No } \\
\text { Yes } \\
\text { Yes }\end{array}$ & Improved & None \\
\hline 4 & $\begin{array}{l}1 \\
2 \\
3\end{array}$ & $\begin{array}{l}6 \\
8 \\
8\end{array}$ & $\begin{array}{l}6 \\
3 \\
3\end{array}$ & $\begin{array}{l}36 \\
24 \\
24\end{array}$ & $\begin{array}{l}\text { No } \\
\text { No } \\
\text { No }\end{array}$ & Unchanged & None \\
\hline 5 & $\star^{\star} 1$ & $\begin{array}{l}6 \\
8\end{array}$ & $\begin{array}{l}8 \\
6\end{array}$ & $\begin{array}{l}48 \\
48\end{array}$ & $\begin{array}{l}\text { Yes } \\
\text { Yes }\end{array}$ & Unchanged & None \\
\hline 6 & $\begin{array}{r}1 \\
\star 2\end{array}$ & $\begin{array}{l}6 \\
8\end{array}$ & $\begin{array}{l}6 \\
4\end{array}$ & $\begin{array}{l}36 \\
32\end{array}$ & $\begin{array}{l}\text { Yes } \\
\text { Yes }\end{array}$ & Improved & None \\
\hline
\end{tabular}

LAD, left anterior descending artery.

*Laser pulse delivered during fibre withdrawal.

seconds over a distance of approximately $1 \mathrm{~cm}$ to avoid adherence of the metal cap to the arterial wall. A laser pulse was also delivered during fibre withdrawal, with at least the same power that was used to cross the stenosis. Angiography was repeated after each laser pulse. At the end of the laser procedure cardiopulmonary bypass was started, an internal mammary artery graft was anastomosed to the lef anterior descending artery, and saphenous veiro grafts were inserted on to the remaining diseaseck coronary branches. Immediately after operation the heparinisation was reversed with protamine sul쿵 phate. In patients with successful laser recanalisation coronary angiography was repeated at 24 hours.

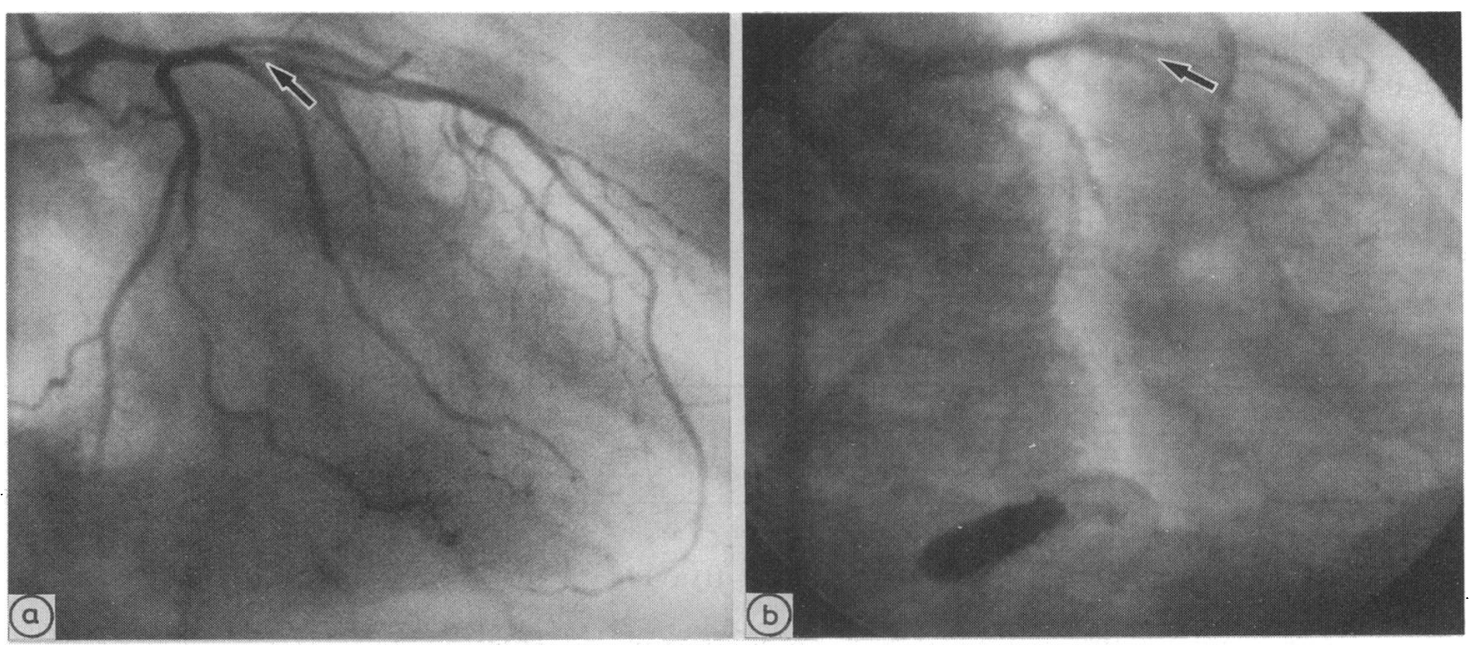

Fig 2 (a) Baseline cineangiogram of patient 3 showing severe stenosis (arrow) of the left anterior descending artery. (b) Angiogram of the left coronary artery (obtained by recording the fluoroscopic image on videotape) immediately after the delivery of laser energy $(132 \mathrm{~J})$. A considerable reduction in the severity of the stenosis of the left anterior descending artery is apparent (arrow); the arterial wall does not show evidence of irregularities. 


\section{Results}

The laser procedure reduced the severity of the left anterior descending artery stenosis in three of the six patients. In patient 2 the delivery of $>112 \mathrm{~J}$ at the same site caused coronary perforation. Therefore, in the subsequent four patients the delivery of laser energy in the attempt to traverse the stenosis was limited to $<90 \mathrm{~J}$. In all cases, inspection of the metal cap after the procedure showed the presence of charred blood which could be scraped off with a scalpel blade. The results are presented in detail below and are summarised in table 2 .

\section{SUCCESSFUL LASER RECANALISATION}

In patient 1 the first laser pulse $(24 \mathrm{~J})$ did not allow the fibre to be advanced through a $3 \mathrm{~cm}$ long $80 \%$ stenosis. The following three laser pulses $(48 \mathrm{~J}, 48 \mathrm{~J}$, and $32 \mathrm{~J}$ ) resulted in the gradual progression of the fibre across the stenosis. A $100 \mathrm{~J}$ laser pulse was delivered during withdrawal. Repeat angiography showed a reduction in the severity of the stenosis.

In patient 3 the initial two laser pulses ( $36 \mathrm{~J}$ and 24 $\mathrm{J}$, respectively) did not allow advancement of the fibre through an $80 \%$ stenosis; this was achieved with the third $24 \mathrm{~J}$ laser pulse. In addition, $48 \mathrm{~J}$ was delivered during fibre withdrawal. In patient 6 a 70\%
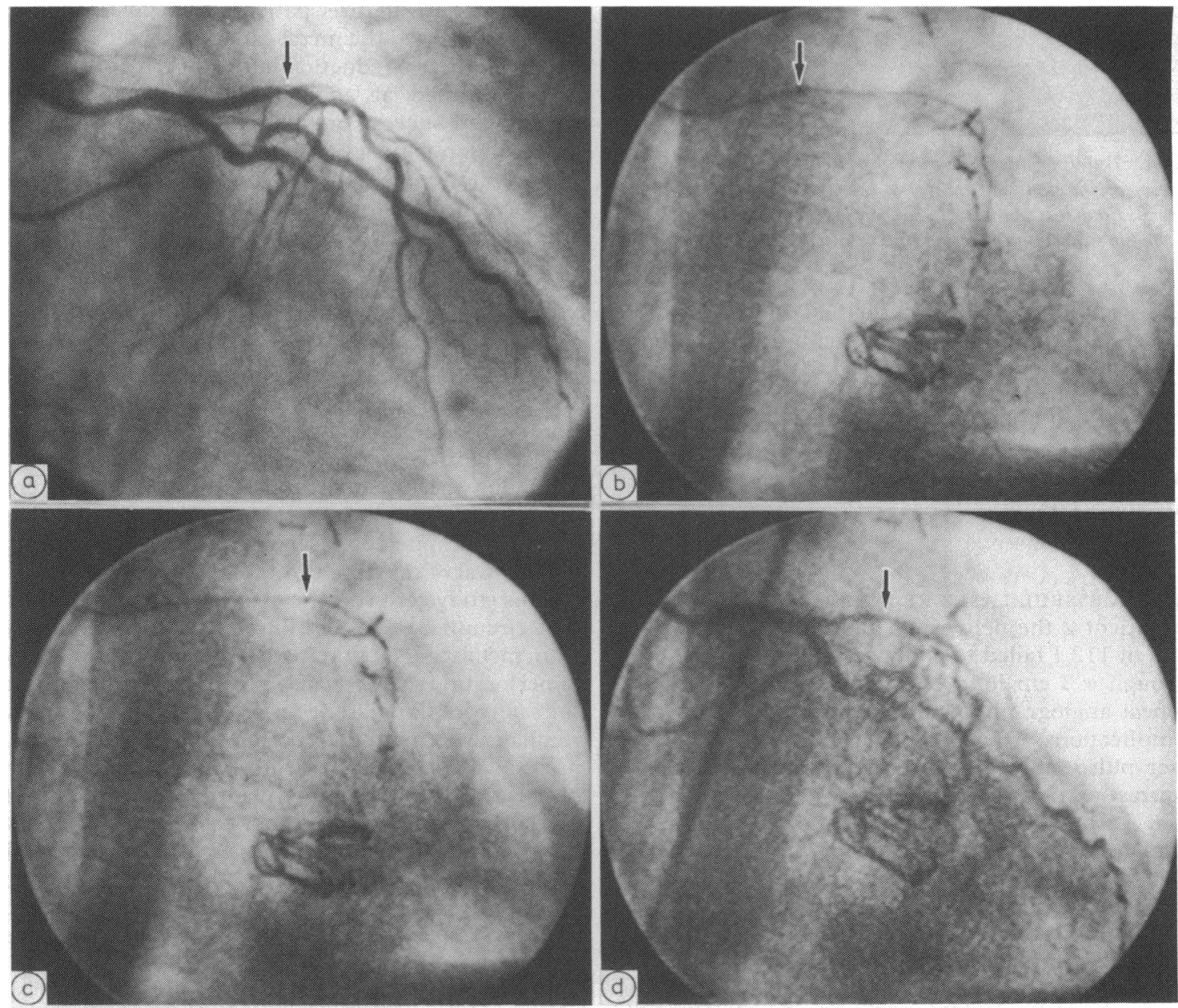

Fig 3 (a) Baseline cineangiogram of patient 6 showing a proximal stenosis of the left anterior descending artery (arrow). (b) Fluoroscopic image recorded on videotape showing the guide wire positioned through the stenosis and the metal cap (arrow) proximal to the stenosis. (c) Fluoroscopic image obtained after the delivery of laser energy which allowed the passage of the optical fibre through the stenosis. The metal cap (arrow) is now distal to the stenosis. (d) Angiogram of the left coronary artery (obtained by recording the fluoroscopic image on videotape) immediately after the delivery of laser energy. There is considerable improvement in the severity of the stenosis (arrow). 


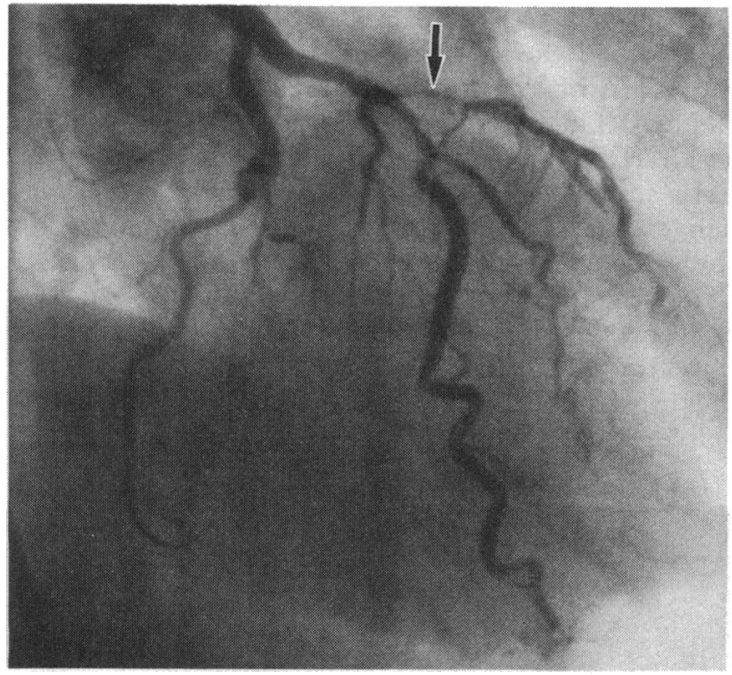

Fig 4 Baseline cineangiogram of patient 2 showing a long severe calcific stenosis (arrow) of the left anterior descending artery. Four laser pulses (192 J) failed to permit the passage of the fibre through the lesion and resulted in perforation.

stenosis was traversed with the first $36 \mathrm{~J}$ laser pulse; $32 \mathrm{~J}$ was delivered during fibre withdrawal. In both cases repeat angiography showed that the severity of the stenosis had been reduced (figs 2 and 3 ).

Angiography at 24 hours demonstrated a patent internal mammary graft in all three patients; in two of these there was total proximal occlusion of the left anterior descending artery.

\section{UNSUCCESSFUL LASER RECANALISATION}

In patient 2 the delivery of three laser pulses for a total of $112 \mathrm{~J}$ failed to allow progression of the fibre through a $3 \mathrm{~cm}$ long $80 \%$ calcific stenosis (fig 4). Repeat angiography at this stage did not show any complications. After the delivery of an additional $80 \mathrm{~J}$ laser pulse, angiography demonstrated periarterial contrast extravasation, indicating coronary perforation. Inspection of the artery showed a localised extravasation of blood contained within the epicardial fat and surrounding a minute perforation. Cardiopulmonary bypass was promptly instituted, the perforation was repaired with a single suture, and grafts were implanted in the normal way.

In patient 4 the fibre failed to cross an $80 \%$ stenosis despite the delivery of three laser pulses (total $84 \mathrm{~J}$ ). During the attempts to advance the fibre, fluoroscopy showed bending of the fibre tip with a loss of alignment of the metal cap within the vessel lumen. Repeat angiography showed that the stenosis was unchanged. In patient 5 the fibre crossed a $70 \%$ stenosis before the delivery of laser energy. The two laser pulses (total energy $96 \mathrm{~J}$ ) delivered during fibre withdrawal did not affect the severity of the stenosis.

In patients 2 and 4 the metal cap adhered to the arterial wall after the delivery of laser energy; a $1 \mathrm{~s}$ laser pulse at a power of $6 \mathrm{~W}$ was necessary in these cases to detach the fibre from the arterial wall.

\section{Discussion}

In this study percutaneous coronary laser recanalisation of a severe stenosis of the left anterior descending artery was attempted in six patients with metal-capped optical fibres at the time of coronary bypass surgery. In three patients the delivery of laser energy permitted the metal cap to cross the stenosis, and in all three a reduction in the severity of stenosis was confirmed at angiography. Multiple factors determined success or failure. The procedure was successful in patient 1 but not in patient 2 , although in both the angiographic severity of the stenoses was similar. On direct observation and palpation during surgery, however, the stenosis in patient 2 was found to be much more tortuous and calcified than was suggested by angiography. It is possible that the heat generated by the metal cap was insufficient to vaporise the calcified component of the atherosclerotic plaque. In patient 4 , although the stenosis was less severe than in patients 1 and 2 , malalignment of the fibre within the vessel lumen probably accounted for the lack of success. In patient 5 the metal cap was too small for the size of the artery and no apparent improvement in the severity of the stenosis was obtained despite the laser energy delivered during withdrawal of the fibre through the stenosis.

This study confirms the experimental observation that circumferential distribution of thermal energy from metal-capped fibres is associated with a low risk of perforation..$^{242527} \mathrm{It}$ also provides information on the safety levels of laser energy which allow coronary recanalisation without perforation-although the precise threshold for perforation is still uncertain because it is difficult to quantify the amount of pressure applied to the optical fibre. Coronary perforation only occurred in one patient when $192 \mathrm{~J}$ was delivered at the same site, but not in the five other patients in whom $<90 \mathrm{~J}$ was used when the delivery of laser energy was not accompanied by fibre progression.

In this early series of patients, to minimise the risk of potentially serious complications the procedure was performed at the time of operation before cardiopulmonary bypass was started. The study design, therefore, does not assess medium and long term patency of treated vessels because occlusion of the left anterior descending artery (proximal to graft 
insertion) was favoured by the competitive flow from the graft, by the reversal of anticoagulation, and by the absence of antiplatelet treatment. In two studies percutaneous coronary laser recanalisation with metal-capped optical fibres was attempted as an adjunct to balloon angioplasty in closed chest patients. ${ }^{29}{ }^{30}$ Cumberland et al used this technique in four patients with a severe coronary stenosis that could only be crossed with a guide wire but not with a balloon catheter. Three of these four high risk patients developed myocardial infarction within 12 hours of the procedure; the mechanism of occlusion was not investigated. ${ }^{29}$ In a later study in patients with less severe coronary stenoses Sanborn et al reported successful laser recanalisation in four of seven patients, apparently without acute complications. ${ }^{30}$

The low primary success rate and the potential problem of early occlusion indicate that this technique will have to be improved before percutaneous coronary laser recanalisation with metal-capped fibres can be recommended.

We thank Trimedyne Inc (Santa Ana, California) and Nytech (Birmingham, UK) for providing the metal-capped optical fibres. We express gratitude to the British Heart Foundation which awarded a fellowship to $\mathrm{B} \mathrm{K}$ for his work in the field of coronary laser revascularisation.

\section{References}

1 Abela GS, Normann SJ, Cohen DM, et al. Laser recanalization of occluded atherosclerotic arteries in vivo and in vitro. Circulation 1985;71:403-11.

2 Ginsburg R, Wexler L, Mitchell RS, Profitt D. Percutaneous transluminal laser angioplasty for treatment of peripheral vascular disease. Radiology 1985;156:619-24.

3 Geschwind HJ, Boussignac G, Teisseire B, Benhaiem N, Bittoun R, Laurent D. Conditions for effective $\mathrm{Nd}-\mathrm{YAG}$ laser angioplasty. $\mathrm{Br}$ Heart $J$ 1984;52:484-9.

4 Abela GS, Crea F, Smith W, Pepine CJ, Conti R. In vitro effects of argon laser radiation on blood: quantitative and morphologic analysis. J Am Coll Cardiol 1985;5:231-7.

5 Case RB, Choy DSJ, Dwyer EM, Silvernail PJ. Absence of distal emboli during in vivo laser recanalisation. Lasers Surg Med 1985;5:281-9.

6 Abela GS, Crea F, Seegar JM, et al. The healing process in normal canine arteries and in atherosclerotic monkey arteries after transluminal laser irradiation. Am J Cardiol 1985;56:983-8.

7 Choy DSJ, Stertzer SH, Rotterdam HZ, Bruno MS. Laser coronary angioplasty: experience with 9 cadaver hearts. Am J Cardiol 1982;50:1206-8.
8 Lee G, Ikeda RM, Kozina J, Mason DT. Laser dissolution of coronary atherosclerotic obstructions. Am Heart J 1981;102:1074-5.

9 Abela GS, Normann S, Cohen D, Feldman RL, Geiser EA, Conti CR. Effects of carbon dioxide, NdYAG and argon laser radiation on coronary atheromatous plaques. Am J Cardiol 1982;50:1199-204

10 Choy DSJ, Stertzer SH, Rotterdam HZ, Sharrock N, Kaminoux IP. Transluminal laser catheter angioplasty. Am J Cardiol 1982;50:1209-11.

11 Crea F, Fenech A, Smith W, Conti CR, Abela GS. Laser recanalization of acutely thrombosed coronary arteries in live dogs: early results. $\mathrm{J} \mathrm{Am}$ Coll Cardiol 1985;6:1052-6.

12 Crea F, Abela GS, Fenech A, Smith W, Pepine CJ, Conti CR. Transluminal laser irradiation of coronary arteries in live dogs: an angiographic and morphologic study of acute effects. Am J Cardiol 1986;57:171-4.

13 Grundfest WS, Litvack F, Forrester JS, et al. Laser ablation of human atherosclerotic plaque without adjacent tissue injury. J Am Coll Cardiol 1985;5:92933.

14 Isner JM, Donaldson RF, Deckelbaum LI, et al. The excimer laser: gross, light microscopic, and ultrastructural analysis of potential advantages for use in laser therapy of cardiovascular disease. J Am Coll Cardiol 1985;6:1102-9.

15 Bowker TJ, Cross FW, Rumsby PT, Gower MC, Rickards AT, Bown SG. Excimer laser angioplasty: quantitative comparison in vitro of three ultraviolet wavelengths on tissue ablation and haemolysis. Lasers in Medical Science 1986;1:91-9.

16 Lee G, Ikeda RM, Stobbe D, et al. Intraoperative use of dual fibre optic catheter for simultaneous in vivo visualization and laser vaporization of peripheral atherosclerotic obstructive disease. Cathet Cardiovasc Diagn 1984;10:11-6.

17 Abela GS, Seegar JM, Barbieri E, et al. Laser angioplasty with angioscopic guidance in humans. $J$ Am Coll Cardiol 1986;8:184-92.

18 Deckelbaum LI, Stetz ML, Lam JK, et al. Fiberoptic laser-induced fluorescence detection of atherosclerosis and plaque ablation: potential for laser angioplasty guidance [Abstract]. Circulation 1986;74(suppl II):7.

19 Geschwind HJ, Blair JD, Mongkolsmai D, et al. Development and experimental application of contact probe catheter for laser angioplasty. J Am Coll Cardiol 1987;9:101-7.

20 Bowker TJ, Fox KM, Poole-Wilson PA, Bown SG, Rickards AF. Acute and chronic angiographic effects of in vivo coronary laser angioplasty [Abstract]. $\mathrm{Br}$ Heart $J$ 1985;54:634.

21 Spears JR, Serur J, Shropshire D, Paulin S. Fluorescence of experimental plaques with haematoporphyrin derivative. J Clin Invest 1983;71:395-9.

22 Murphy-Chutorian D, Kosek J, Mok W, et al. Selective absorption of ultraviolet laser energy by human atherosclerotic plaque treated with tetracycline. $\mathrm{Am} \mathrm{J}$ Cardiol 1985;55:1293-7.

23 Abela GS, Barbieri E, Roxey T, Conti CR. Laser enhanced plaque atheroloysis with tetracycline [Abstract]. Circulation 1986;74(suppl II):7. 
24 Abela GS, Fenech A, Crea F, Conti CR. "Hot tip": another method of laser vascular recanalization. Lasers Surg Med 1985;5:327-35.

25 Sanborn TA, Faxon DP, Haudenschild C, Ryan TJ. Experimental angioplasty: circumferential distribution of laser thermal energy with a laser probe. $J \mathrm{Am}$ Coll Cardiol 1985;5:934-8.

26 Hussein $\mathrm{H}$. A novel fiberoptic laser probe for treatment of occlusive vessel disease. Optical Laser Technol Med 1986;605:59-66.

27 Cumberland DC, Sanborn TA, Taylor DI, et al. Percutaneous laser thermal angioplasty: initial clinical results with a laser probe in total peripheral artery $c$ occlusions. Lancet 1986;i:1457-9.

28 Crea F, Davies G, McKenna W, et al. Transluminal lasing of coronary arteries with a metal-capped opticalo fibre: experimental and early clinic results [Abstract]. Lasers in Medical Science 1986;1:312-3.

29 Cumberland DC, Starkey IR, Oakley GDG, et al. Percutaneous laser-assisted coronary angioplasty [Letter]. Lancet 1986;ii:214.

30 Sanborn TA, Faxon DP, Kellett MA, Ryan TJ. $\vec{\circ}$ Percutaneous coronary laser thermal angioplasty. $J$ Am Coll Cardiol 1986;8:1437-40. 